\title{
Detection and molecular characterization of Cryptosporidium spp. in captive canaries (Serinus canaria) using different diagnostic methods
}

Detecção e caracterização molecular de Cryptosporidium spp. em canários mantidos em cativeiro (Serinus canaria) por diferentes métodos de diagnóstico

Vinícius da Silva Camargo ${ }^{1}$; Bruna Nicoleti Santana ${ }^{1}$; Elis Domingos Ferrari ${ }^{1}$; Alex Akira Nakamura ${ }^{2}$; Walter Bertequini Nagata ${ }^{1}$; Ana Rita Moraes Nardi ${ }^{3}$; Marcelo Vasconcelos Meireles ${ }^{1 *}$

\author{
${ }^{1}$ Faculdade de Medicina Veterinária, Universidade Estadual Paulista - UNESP, Araçatuba, SP, Brasil \\ ${ }^{2}$ Curso de Medicina Veterinária, Faculdades Adamantinenses Integradas, Adamantina, SP, Brasil \\ ${ }^{3}$ Fundação Municipal de Ensino Superior, Bragança Paulista, SP, Brasil
}

Received October 2, 2017

Accepted January 17, 2018

\begin{abstract}
This study used several diagnostic methods to examine the occurrence of and molecularly characterize Cryptosporidium spp. in captive canaries (Serinus canaria) in southern and southeastern Brazil. A total of 498 fecal samples were purified by centrifugal-flotation using Sheather's solution. Cryptosporidium spp. diagnosis was performed using three diagnostic methods: malachite green negative staining, nested PCR targeting the 18S rRNA gene, followed by sequencing the amplified fragments, and duplex real-time PCR targeting the 18S rRNA specific to detect Cryptosporidium galli and Cryptosporidium avian genotype III. The overall positivity for Cryptosporidium spp. (total samples positive in at least one protocol) from the microscopic analysis, nested PCR and duplex real-time PCR protocol results was $13.3 \%(66 / 498)$. The positivity rates were $2.0 \%$ (10/498) and 4.6\% (23/498) for Cryptosporidium spp. by microscopy and nested PCR, respectively. Sequencing of 20 samples amplified by nested PCR identified C. galli (3.0\%; 15/498), Cryptosporidium avian genotype I $(0.8 \% ; 4 / 498)$ and Cryptosporidium avium $(0.2 \% ; 1 / 498)$. Duplex real-time PCR revealed a positivity of 7.8\% (39/498) for C. galli and 2.4\% (12/498) for avian genotype III. Malachite green negative staining differed significantly from nested PCR in detecting Cryptosporidium spp. Duplex real-time PCR was more sensitive than nested $\mathrm{PCR} /$ sequencing for detecting gastric Cryptosporidium in canaries.
\end{abstract}

Keywords: Cryptosporidiosis, birds, diagnosis, epidemiology.

\section{Resumo}

Este trabalho teve como objetivos determinar a ocorrência e realizar a caracterização molecular de Cryptosporidium spp. em 498 amostras fecais de canários (Serinus canaria) criados em cativeiro, utilizando três métodos de diagnóstico: análise microscópica pela coloraçáo negativa com verde malaquita, nested PCR seguida de sequenciamento dos fragmentos amplificados e PCR duplex em tempo real específica para detecção de Cryptosporidium galli e Cryptosporidium genótipo III de aves. A positividade total para Cryptosporidium spp. (total de amostras positivas em pelo menos um método de diagnóstico) obtida pela análise microscópica, nested PCR e PCR duplex em tempo real foi de 13,3\% (66/498). As taxas de positividade para Cryptosporidium spp. foram 2,0\% (10/498) e 4,6\% (23/498) por microscopia e nested PCR, respectivamente. O sequenciamento de 20 amostras amplificadas pela nested PCR identificou C. galli (3,0\%; 15/498), Cryptosporidium genótipo I de aves $(0,8 \% ; 4 / 498)$ e Cryptosporidium avium $(0,2 \% ; 1 / 498)$. A PCR duplex em tempo real revelou positividade de 7,8\% (39/498) para C. galli e 2,4\% (12/498) para Cryptosporidium genótipo III de aves. A análise microscópica diferiu significativamente da nested PCR para detecção de Cryptosporidium spp. A PCR duplex em tempo real apresentou maior sensibilidade que a nested $\mathrm{PCR} /$ sequenciamento para detectar as espécies/genótipos gástricos de Cryptosporidium.

Palavras-chave: Criptosporidiose, aves, diagnóstico, epidemiologia.

*Corresponding author: Marcelo Vasconcelos Meireles. Faculdade de

Medicina Veterinária, Universidade Estadual Paulista - UNESP, Rua Clóvis

Pestana, 793, Bairro Dona Amélia, CEP 16050-680, Araçatuba, SP, Brasil.

e-mail: marcelo@fmva.unesp.br 


\section{Introduction}

Cryptosporidiosis is a major protozoan infection in birds, causing respiratory and gastrointestinal diseases in domestic and wild species (NAKAMURA \& MEIRELES, 2015). Four Cryptosporidium species infect birds: C. meleagridis (SLAVIN, 1955), C. baileyi (CURRENT et al., 1986), C. galli (RYAN et al., 2003a) and C. avium (formerly avian genotype V) (HOLUBOVÁ et al., 2016). In addition to the avian Cryptosporidium species, many genotypes infect birds, mainly the avian genotypes I (NG et al., 2006), II (SANTOS et al., 2005; MEIRELES et al., 2006; NG et al., 2006), and III (NG et al., 2006).

Studies conducted in several countries, with several species of domestic and wild birds, reported that Cryptosporidium spp. prevalence ranged from $0.8 \%$ to $44.4 \%$, and $C$. andersoni, C. avium, C. baileyi, C. galli, C. muris, C. meleagridis, and C. parvum and several avian genotypes, including the avian genotypes I, II, III and VI were identified (NAKAMURA \& MEIRELES, 2015, CHELLADURAI et al., 2016).

In Brazil, C. avium, C. baileyi, C. meleagridis, C. parvum, the avian genotypes I, II and III and the duck genotype were reported to occur in fecal samples of domestic and wild birds (MEIRELES \& FIGUEIREDO, 1992; SANTOS et al., 2005; MEIRELES et al., 2006; HUBER et al., 2007; NAKAMURA et al., 2009, 2014; SEVÁ et al., 2011; NARDI, 2015; CUNHA et al., 2017).

C. galli is the most frequent species in Passeriformes; however, there is controversy regarding its pathogenicity in birds (NAKAMURA \& MEIRELES, 2015). C. galli or Cryptosporidium avian genotype III infections can result in diarrhea, anorexia, weight loss, and chronic vomiting (ANTUNES et al., 2008; MAKINO et al., 2010, SILVA et al., 2010; RAVICH et al., 2014).

In canaries (Serinus canaria), C. galli, C. avium and C. avian genotypes I and III infections have been described (NG et al., 2006; ANTUNES et al., 2008; NAKAMURA et al., 2009, 2014; NARDI, 2015). Most epidemiological studies on avian cryptosporidiosis were performed using convenience sampling with fecal samples from several bird species (NG et al., 2006; NAKAMURA et al., 2009, SEVÁ et al., 2011; BAMAIYI et al., 2013; REBOREDO-FERNÁNDEZ et al., 2015).

Parasite-host adaptation and co-evolution among Cryptosporidium spp. and their avian hosts are thought to occur (XIAO et al., 2002) since some Cryptosporidium species/genotypes are found almost exclusively in certain avian orders (NAKAMURA \& MEIRELES, 2015). Therefore, epidemiological studies using samples representing avian orders or species would aid in investigating Cryptosporidium species evolution.

The common techniques used to diagnose Cryptosporidium infection are microscopic analysis and nested PCR. Microscopy is an inexpensive and fast technique; however, it does not identify the Cryptosporidium species and is less sensitive and specific. Nested PCR is more expensive than microscopy, despite being highly sensitive and specific and identifying the species after amplicon sequencing (JEX et al., 2008). Another option for specific species/genotype diagnosis of gastric cryptosporidiosis in birds is through duplex real-time PCR (NAKAMURA et al., 2014).
The aim of the present study was to determine the prevalence of Cryptosporidium spp. in fecal samples from captive canaries from southern and southeastern Brazil. Additionally, molecular characterization of positive samples was performed, and three techniques for detecting Cryptosporidium spp. were compared.

\section{Materials and Methods}

This study was approved by the Animal Use Ethics Committee (CEUA) of the São Paulo State University (UNESP), School of Veterinary Medicine, Araçatuba, process FOA 01022-2015.

\section{Fecal samples}

Fecal samples were obtained from asymptomatic captive canaries housed in 102 aviaries from six southern and southeastern Brazilian states, exhibited at the 64th Ornithological Championship 2015 of the Ornithological Federation of Brazil (FOB), from 09/07/2015 to $19 / 07 / 2015$, in the city of Itatiba, state of São Paulo, Brazil.

The total population of canaries exhibited in the championship was approximately 40,000 birds. To determine the prevalence of Cryptosporidium spp. in these canaries, the sample number of 385 was calculated using Win Episcope software (THRUSFIELD et al., 2001) considering a diagnostic test with $100 \%$ sensitivity and $100 \%$ specificity. As lower sensitivity and specificity rates are common when using the diagnostic protocols employed in this study (JEX et al., 2008), and because losses occur in sample storage and processing, 498 samples were collected.

Samples were collected from the bottom of the cage at the time of the bird's reception at the championship to avoid cross-contamination. Each sample was collected using a disposable wooden spatula, transferred to a $2-\mathrm{ml}$ microtube containing $0.9 \%$ sodium chloride solution in enough quantity to prevent dehydration, and stored at $4^{\circ} \mathrm{C}$.

\section{Purification of oocysts}

Samples were fragmented and homogenized using a disposable wooden spatula in a $2 \mathrm{~mL}$ microtube containing Sheather's solution $(\mathrm{g}=2.05)$ prepared with phosphate buffered saline and $0.1 \%$ Tween 20 (PBS-T). The contents of each microtube were homogenized, and half of the contents were transferred to another microtube so that each sample was purified in two tubes simultaneously. Each microtube was filled with $1.9 \mathrm{~mL}$ of Sheather's solution and vortexed and centrifuged at $800 \mathrm{~g}$ for 5 minutes. Four hundred $\mu \mathrm{L}$ of supernatant was transferred to a microtube containing $1,500 \mu \mathrm{L}$ of PBS-T, homogenized by inversion and centrifuged at $10,000 \mathrm{~g}$ for 3 minutes. After discarding the supernatant, the microtubes were filled with $1.9 \mathrm{~mL}$ of PBS with $0.01 \%$ Tween 20 and centrifuged at $10,000 \mathrm{~g}$ for 3 minutes. The supernatant was discarded, preserving approximately $100 \mu \mathrm{L}$ of solution and sediment. One hundred $\mu \mathrm{L}$ of $10 \%$ buffered formalin was added to one microtube for Cryptosporidium oocyst microscopy screening using malachite green negative staining (ELLIOT et al., 1999), 
while the other microtube was frozen at $-20^{\circ} \mathrm{C}$ for DNA extraction and amplification by nested PCR and duplex real-time PCR.

\section{Genomic DNA extraction}

Genomic DNA of Cryptosporidium spp. was extracted per the protocol adapted from McLauchlin et al. (2000) and Wang et al. (2011) using Zymo-Spin ${ }^{\circledR}$ IIIC silica columns (Zymo Research, Irvine, USA) to replace activated silica. The DNA was eluted in $100 \mu \mathrm{L}$ of elution buffer (10 mM Tris, $0.5 \mathrm{mM}$ EDTA, $\mathrm{pH}$ 9) and stored at $-20^{\circ} \mathrm{C}$ in two $50 \mu \mathrm{L}$ aliquots.

\section{Nested PCR and sequencing}

Nested PCR targeting the 18S rRNA gene was performed using the PCR primers, 5'-GACATATCATTCAAGTTTCTGACC-3' and 5'-CTGAAGGAGTAAGGAACAACC-3' ( $761 \mathrm{bp})$, and the nested PCR primers, 5'-CCTATCAGCTTTAGACGGTAGG-3' and 5'-TCTAAGAATTTCACCTCTGACTG-3' ( -585 bp) (RYAN et al., 2003b). Genomic DNA from C. parvum and ultrapure water were used as positive and negative controls, respectively.

The reactions contained a volume of $25 \mu \mathrm{L}$, with $2.5 \mu \mathrm{L}$ of 10x PCR buffer, $2.0 \mathrm{mM} \mathrm{MgCl}, 0.5 \mathrm{U}$ of JumpStart ${ }^{\circledR}$ Taq DNA Polymerase (Sigma-Aldrich, St. Louis, USA), $200 \mu \mathrm{M}$ of each deoxyribonucleotide, $200 \mathrm{nM}$ of each primer, $5 \mu \mathrm{L}$ of target DNA in the PCR and $2.5 \mu \mathrm{L}$ of DNA in the nested PCR. Samples were subjected to initial DNA denaturation at $94^{\circ} \mathrm{C}$ for 2 minutes, followed by 40 cycles, each consisting of denaturation at $94^{\circ} \mathrm{C}$ for 30 seconds, annealing at $58^{\circ} \mathrm{C}$ and extension at $72^{\circ} \mathrm{C}$ for 60 seconds (PCR) or 45 seconds (nested PCR), with a final extension at $72^{\circ} \mathrm{C}$ for 7 minutes. Amplified fragments were analyzed by GelRed ${ }^{\circledR}$ (Biotium, Fremont, USA) stained gel electrophoresis.

\section{Duplex real-time PCR}

Duplex real-time PCR was performed to simultaneously detect C. galli and Cryptosporidium avian genotype III (NAKAMURA et al., 2014), amplifying 134-bp and 138-bp amplicons, respectively (Table 1), under the following reaction conditions: $25 \mu \mathrm{L}$ of solution containing $12.5 \mu \mathrm{L}$ of JumpStart ${ }^{\circledR}$ TaqReady Mix (Sigma-Aldrich, St. Louis, USA), $4.5 \mathrm{mM} \mathrm{MgCl}_{2}, 250 \mathrm{nM}$ of each probe, $600 \mathrm{nM}$ of each primer, $0.6 \mu \mathrm{g} / \mu \mathrm{L}$ of non-acetylated bovine serum albumin (Sigma-Aldrich, St. Louis, USA), and $5 \mu \mathrm{L}$ of target DNA. PCR cycles consisted of 2 minutes of denaturation at $94^{\circ} \mathrm{C}$ followed by 50 cycles of 30 seconds at $94^{\circ} \mathrm{C}$ and 1 minute at $61^{\circ} \mathrm{C}$ in the $\mathrm{CFX} 96^{\circledR}$ Real-Time PCR Detection System (Bio-Rad, Hercules, USA).

\section{$D N A$ sequencing}

Identifying the Cryptosporidium species was performed by sequencing the nested PCR amplicons, after purification using the Illustra ExoProStar ${ }^{\circledR}$ 1-Step (GE Healthcare Life Sciences, Champaign, USA) or the QIAquick ${ }^{\circledR}$ Gel Extraction kit (Qiagen, Hilden, Germany), using ABI Prism ${ }^{\circledR}$ Dye Terminator 3.1, in an ABI 3730XL automatic sequencer (Applied Biosystems, Foster City, USA), at the Center for Sequencing and Functional Genomics of UNESP, Jaboticabal Campus, Brazil. Sequencing reactions were performed in both directions using nested PCR primers.

Consensus sequences were determined using the CodonCode Aligner v. 7.1.2 (CodonCode Corporation, Dedham, USA) and aligned with homologous sequences published in GenBank using Clustal X software (THOMPSON et al., 1997) and Bioedit Sequence Alignment Editor (HALL, 1999).

Nucleotide sequences generated in this study were submitted to the GenBank database under the accession numbers MG832881-MG832883.

\section{Statistical analysis}

The McNemar test was used to compare diagnostic techniques, and the Kappa correlation coefficient test was used to evaluate the agreement between them. Statistical analyses were performed using the BioEstat 5.0 software (Analyst Soft Inc., Walnut, USA) and the results were considered significant when $\mathrm{p}<0.05$.

\section{Results and Discussion}

The overall positivity rates for Cryptosporidium spp. (total samples positive in at least one protocol) were $13.3 \%(66 / 498)$ and $40.2 \%$ (41/102) for fecal samples and aviaries, respectively (Table 2). By microscopy and nested PCR, the positivity rates for Cryptosporidium spp. were 2.0\% (10/498) and 4.6\% (23/498), respectively. There was a significant difference $(\mathrm{p}=0.01)$ and a fair agreement (Kappa $=0.28$ ) between nested PCR and microscopic analysis for detecting Cryptosporidium spp.

Only one study has reported specifically on Cryptosporidium infection in canaries (NARDI, 2015), with the reported positivity for Cryptosporidium spp. in asymptomatic canaries at 2\% (8/394) in Ziehl-Neelsen stained fecal samples. This is consistent with

Table 1. Primers and probes used to detect C. galli and Cryptosporidium avian genotype III by duplex real-time PCR.

\begin{tabular}{lcc}
\hline \multicolumn{1}{c}{ Species/Genotype } & Primers/ Probes & Sequence 5'-3' \\
\hline C. galli & Forward primer & CGTAGTTGGATTTCTGTTGCATCA \\
& Probe & FAM AATATAATATCAACATCCTCCC MGB \\
& Rewind primer & GGCAGTTGCCTGCTTTAAGC \\
Cryptosporidium avian & Forward primer & GCTCGTAGTTGGATTTCTGTTGTATT \\
genotype III & Probe & VIC CATTATAATAACAACATCCTTCC MGB \\
& Rewind primer & GGCAGTTGCCTGCTTTAAGC \\
\hline
\end{tabular}


the results of the present study using malachite green negative staining $(2 \% ; 10 / 498)$.

Nested PCR/sequencing revealed the presence of $C$. galli (3\%; 15/498), Cryptosporidium avian genotype I (0.8\%; 4/498), and $C$. avium $(0.2 ; 1 / 498)$ (Table 3$)$. Sequences from C. galli, Cryptosporidium avian genotype I and $C$. avium were $100 \%$ similar to GenBank homologous sequences EU543269 (S. canaria), GQ227479 (S. canaria) and KJ487974 (Amazona aestiva), respectively. Unexpected nonspecific nested PCR amplification of Isospora spp. amplicons of the predicted sizes occurred in six samples. Because nested PCR primers target conserved regions of a pan-eukaryotic gene (18S rRNA), diagnosis of Cryptosporidium spp. based only on $18 \mathrm{~S}$ rRNA amplicon sizes should be confirmed with caution in Passeriformes, since Isospora spp. is common in fecal samples from birds of this order (BERTO et al., 2011).
Duplex real-time PCR was positive for gastric Cryptosporidium in 10.2\% (51/498) of the samples, 7.8\% (39/498) for C. galli and $2.4 \%$ (12/498) for Cryptosporidium avian genotype III. For detecting the gastric species of Cryptosporidium, nested PCR/sequencing and duplex real-time PCR were significantly different $(\mathrm{p}<0.0001)$, and the agreement between the two methods was fair (Kappa $=0.40)$.

C. galli is associated with chronic infection in the passerine proventriculus and is likely responsible for chronic gastric disease and predisposition to concomitant infections (ANTUNES et al., 2008; NAKAMURA \& MEIRELES, 2015). The species most frequently detected by nested PCR/sequencing was $C$. galli, corresponding to $75 \%(15 / 20)$ of the sequenced samples. In addition, Cryptosporidium species identification by nested PCR/sequencing and duplex real-time PCR revealed results similar to those of other authors (NAKAMURA et al., 2014; NARDI, 2015), in which

Table 2. Results of positivity for Cryptosporidium spp., in at least one protocol, from canary fecal samples from southern and southeastern Brazil.

\begin{tabular}{|c|c|c|c|c|}
\hline \multirow[b]{2}{*}{$\begin{array}{l}\text { States of } \\
\text { Brazil }\end{array}$} & \multicolumn{2}{|r|}{ Fecal samples } & \multicolumn{2}{|r|}{ Aviaries } \\
\hline & 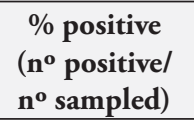 & $\begin{array}{c}\text { Species identification } \\
\% \text { positive }\left(\mathrm{n}^{\circ} \text { positive } / \mathrm{n}^{\circ} \text { sampled }\right)\end{array}$ & 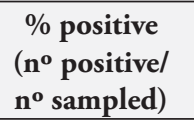 & $\begin{array}{c}\text { Species identification } \\
\% \text { positive ( } \mathrm{n}^{\circ} \text { positive/ } \mathrm{n}^{\circ} \text { sampled) }\end{array}$ \\
\hline São Paulo & $10.9(29 / 267)$ & $\begin{array}{c}\text { C. galli } 48.2(14 / 29) \\
\text { C. avium } 3.4(1 / 29) \\
\text { Avian genotype III } 17.2(5 / 29) \\
\text { Avian genotype I } 3.4(1 / 29) \\
\text { Cryptosporidium sp.* } 27.5(8 / 29)\end{array}$ & $32.8(22 / 67)$ & $\begin{array}{c}\text { C. galli } 17.9(12 / 67) \\
\text { C. avium } 1.4(1 / 67) \\
\text { Avian genotype III } 6(4 / 67) \\
\text { Avian genotype I } 3(2 / 67) \\
\text { Cryptosporidium sp. } 7.4(5 / 67)\end{array}$ \\
\hline Paraná & $14(18 / 128)$ & $\begin{array}{c}\text { C. galli } 50(9 / 18) \\
\text { Cryptosporidium sp. } 22.2(4 / 18) \\
\text { Avian genotype III } 16.6(3 / 18) \\
\text { Avian genotype I } 5.5(1 / 18) \\
\text { C. galli and avian genotype III } 5.5(1 / 18)\end{array}$ & $58.8(10 / 17)$ & $\begin{array}{c}\text { C. galli } 47(8 / 17) \\
\text { Cryptosporidium sp. } 17.6(3 / 17) \\
\text { Avian genotype III 17.6 (3/17) } \\
\text { Avian genotype I } 5.8(1 / 17) \\
\text { C. galli and avian genotype III } 5.8(1 / 17)\end{array}$ \\
\hline $\begin{array}{l}\text { Rio Grande } \\
\text { do Sul }\end{array}$ & $9.3(4 / 43)$ & $\begin{array}{l}\text { C. galli } 75 \text { (3/4) } \\
\text { Avian genotype I } 25(1 / 4)\end{array}$ & $33.3(2 / 6)$ & $\begin{array}{c}\text { C. galli } 33.3(2 / 6) \\
\text { Avian genotype III } 16.6(1 / 6)\end{array}$ \\
\hline Minas Gerais & $17.1(6 / 35)$ & $\begin{array}{c}\text { C. galli } 83.3(5 / 6) \\
\text { Avian genotype III } 16.7(1 / 6)\end{array}$ & $100(2 / 2)$ & $\begin{array}{c}\text { C. galli } 100(2 / 2) \\
\text { Avian genotype III } 50(1 / 2)\end{array}$ \\
\hline Santa Catarina & $53.8(7 / 13)$ & $\begin{array}{c}\text { C. galli } 71.4(5 / 7) \\
\text { Avian genotype III 14.3(1/7) } \\
\text { C. galli and avian genotype III } 14.3(1 / 7)\end{array}$ & $75(3 / 4)$ & $\begin{array}{c}\text { C. galli } 75(3 / 4) \\
\text { Avian genotype III } 25(1 / 4) \\
\text { C. galli and avian genotype III } 25(1 / 4)\end{array}$ \\
\hline Rio de Janeiro & $16.7(2 / 12)$ & C. galli $100(2 / 2)$ & $33.3(2 / 6)$ & C. galli 33.3 (2/6) \\
\hline Total & $13.3(66 / 498)$ & & $40.2(41 / 102)$ & \\
\hline
\end{tabular}

*Samples not sequenced.

Table 3. Detection and identification of Cryptosporidium species and genotypes in canary fecal samples using microscopy and molecular methods targeting the $18 \mathrm{~S}$ rRNA gene.

\begin{tabular}{|c|c|c|c|c|c|}
\hline \multirow{3}{*}{ Diagnostic methods } & \multicolumn{5}{|c|}{ Cryptosporidium detection/identification ( $\mathrm{n}^{\circ}$ positive/ $\mathrm{n}^{\circ}$ sampled) } \\
\hline & \multirow{2}{*}{$\begin{array}{c}\text { Cryptosporidium } \\
\text { spp.* }\end{array}$} & Gastric $C r$ & idium species** & \multirow{2}{*}{$\begin{array}{l}\text { Cryptosporidium } \\
\text { avian genotype I }\end{array}$} & \multirow[b]{2}{*}{ C. avium } \\
\hline & & C. galli & $\begin{array}{l}\text { Cryptosporidium } \\
\text { avian genotype III }\end{array}$ & & \\
\hline
\end{tabular}

$\begin{array}{lc}\text { Malachite green } & 2.0(10 / 498) \\ \text { negative staining } & \\ \text { Nested PCR } & 4.6(23 / 498) \\ \text { Nested PCR/ sequencing } & - \\ \text { Duplex real-time PCR } & -\end{array}$


C. galli showed higher positivity than Cryptosporidium avian genotype III in Passeriformes, including canaries.

Cryptosporidium avian genotype VI, described by Chelladurai et al. (2016), is closely related to C. galli and Cryptosporidium avian genotype III and likely infects the gastric epithelia. Although we did not detect avian genotype VI in canary samples by nested $\mathrm{PCR} /$ sequencing, we cannot assure that duplex real-time PCR does not detect this genotype due to the high similarities in its primer and probe annealing regions.

Tissue tropism and the clinical importance of Cryptosporidium avian genotype I are undetermined (NAKAMURA \& MEIRELES, 2015). Herein, C. galli was detected more frequently in canaries than Cryptosporidium avian genotype I. In contrast, Nardi (2015) found a 14.2\% (29/204) positivity for Cryptosporidium avian genotype I in fecal samples and cloacal swabs from canaries. This higher positivity rate may have resulted from cloacal swab sampling and by including samples from symptomatic and dead birds. Although the tissue tropism of avian genotype $\mathrm{I}$ is undetermined, the close genetic similarity among this genotype, C. avium, C. baileyi and avian genotype II is evidence that avian genotype I exhibits tropism for the cloacal epithelia, the bursa of Fabricius or the respiratory tract (NAKAMURA \& MEIRELES, 2015).

C. avium was identified in one sample and has been described in the trachea/lung and cloaca of a cockatiel (ABE et al., 2015), the kidney and cloaca (CURTISS et al., 2015) and in fecal samples of budgerigars, Amazon parrots, cockatiels and Major Mitchell's cockatoos (ABE \& MAKINO; 2010; QI et al., 2011; NAKAMURA et al., 2014; ZHANG et al., 2015). Nardi (2015) also found low positivity $(1.0 \% ; 2 / 204)$ for $C$. avium in canary fecal samples.

In conclusion, nested PCR was more sensitive than microscopic analysis using malachite green negative staining to detect Cryptosporidium spp. in fecal samples from canaries. Duplex real-time PCR was more sensitive than nested PCR/sequencing for diagnosing gastric cryptosporidiosis in canaries. There was a higher prevalence of C. galli, and Cryptosporidium avian genotype III, Cryptosporidium avian genotype I and C. avium were detected at lower positivity rates.

\section{References}

Abe N, Makino I. Multilocus genotypic analysis of Cryptosporidium isolates from cockatiels, Japan. Parasitol Res 2010; 106(6): 1491-1497. PMid:20339870. http://dx.doi.org/10.1007/s00436-010-1810-5.

Abe N, Matsuo K, Makino I. Ascaridia nymphii n. sp. (Nematoda: Ascaridida) from the alimentary tract of a severely emaciated dead cockatiel Nymphicus hollandicus. Parasitol Res 2015; 114(11): 42814288. PMid:26276643. http://dx.doi.org/10.1007/s00436-015-4668-8.

Antunes RG, Simôes DC, Nakamura AA, Meireles MV. Natural infection with Cryptosporidium galli in canaries (Serinus canaria), in a cockatiel (Nymphicus hollandicus), and in lesser seed-finches (Oryzoborus angolensis) from Brazil. Avian Dis 2008; 52(4): 702-705. PMid:19166068. http:// dx.doi.org/10.1637/8356-051208-Case.1.

Bamaiyi PH, Umoh JU, Abdu PA, Lawal IA. The prevalence of Cryptosporidium oocysts in Zaria, Nigeria. Borneo J Resour Sci Tech 2013; 2(2): 52-59.
Berto BP, Flausino W, McIntosh D, Teixeira-Filho WL, Lopes CWG. Coccidia of New World passerine birds (Aves: Passeriformes): a review of Eimeria Schneider, 1875 and Isospora Schneider, 1881 (Apicomplexa: Eimeriidae). Syst Parasitol 2011; 80(3): 159-204. PMid:22002022. http:// dx.doi.org/10.1007/s11230-011-9317-8.

Chelladurai JJ, Clark ME, Kváč M, Holubová N, Khan E, Stenger BL, et al. Cryptosporidium galli and novel Cryptosporidium avian genotype VI in North American red-winged blackbirds (Agelaius phoeniceus). Parasitol Res 2016; 115(5): 1901-1906. PMid:26818945. http://dx.doi.org/10.1007/ s00436-016-4930-8.

Cunha MJR, Cury MC, Santín M. Molecular identification of Enterocytozoon bieneusi, Cryptosporidium, and Giardia in Brazilian captive birds. Parasitol Res 2017; 116(2): 487-493. PMid:27815734. http://dx.doi.org/10.1007/ s00436-016-5309-6.

Current WL, Upton SJ, Haynes TB. The life cycle of Cryptosporidium baileyi n. sp. (Apicomplexa, Cryptosporidiidae) infecting chickens. J Protozool 1986; 33(2): 289-296. PMid:3735157. http://dx.doi. org/10.1111/j.1550-7408.1986.tb05608.x.

Curtiss JB, Leone AM, Wellehan JF Jr, Emerson JA, Howerth EW, Farina LL. Renal and cloacal cryptosporidiosis (Cryptosporidium avian genotype V) in a Major Mitchell's cockatoo (Lophochroa leadbeateri). J Zoo Wildl Med 2015; 46(4): 934-937. PMid:26667555. http://dx.doi. org/10.1638/2015-0025.1

Elliot A, Morgan UM, Thompson RCA. Improved staining method for detecting Cryptosporidium oocysts in stools using malachite green. J Gen Appl Microbiol 1999; 45(3): 139-142. PMid:12501386. http://dx.doi. org/10.2323/jgam.45.139.

Hall T. BioEdit: a user-friendly biological sequence alignment editor and analysis program for Windows 95/98/NT. Nucleic Acids Symp Ser 1999; 41: 95-98.

Holubová N, Sak B, Horčičková M, Hlásková L, Květoňová D, Menchaca S, et al. Cryptosporidium avium n. sp. (Apicomplexa: Cryptosporidiidae) in birds. Parasitol Res 2016; 115(6): 2243-2251. PMid:26905074. http:// dx.doi.org/10.1007/s00436-016-4967-8.

Huber F, da Silva S, Bomfim TCB, Teixeira KRS, Bello AR. Genotypic characterization and phylogenetic analysis of Cryptosporidium sp. from domestic animals in Brazil. Vet Parasitol 2007; 150(1-2): 65-74. PMid:17905514. http://dx.doi.org/10.1016/j.vetpar.2007.08.018.

Jex AR, Smith HV, Monis PT, Campbell BE, Gasser RB. Cryptosporidium - biotechnological advances in the detection, diagnosis, and analysis of genetic variation. Biotechnol Adv 2008; 26(4): 304-317. PMid:18430539. http://dx.doi.org/10.1016/j.biotechadv.2008.02.003.

Makino I, Abe N, Reavill DR. Cryptosporidium avian genotype III as a possible causative agent of chronic vomiting in peach-faced lovebirds (Agapornis roseicollis). Avian Dis 2010; 54(3): 1102-1107. PMid:20945797. http://dx.doi.org/10.1637/9227-123009-Case.1.

McLauchlin J, Amar C, Pedraza-Díaz S, Nichols GL. Molecular epidemiological analysis of Cryptosporidium spp. in the United Kingdom: results of genotyping Cryptosporidium spp. in 1,705 fecal samples from humans and 105 fecal samples from livestock animals. J Clin Microbiol 2000; 38(11): 3984-3990. PMid:11060056.

Meireles MV, Figueiredo PC. Isolamento e identificação do Cryptosporidium baileyi Current et alii, 1986 (Apicomplexa: Cryptosporidiidae) em frangos de corte. Rev Bras Parasitol Vet 1992; 1(2): 125-130.

Meireles MV, Soares RM, Santos MM, Gennari SM. Biological studies and molecular characterization of a Cryptosporidium isolate from ostriches 
(Struthio camelus). J Parasitol 2006; 92(3): 623-626. PMid:16884009. http://dx.doi.org/10.1645/0022-3395(2006)92[623:BSAMCO]2.0.CO;2.

Nakamura AA, Homem CG, Silva AMJ, Meireles MV. Diagnosis of gastric cryptosporidiosis in birds using a duplex real-time PCR assay. Vet Parasitol 2014; 205(1-2): 7-13. PMid:25155280. http://dx.doi. org/10.1016/j.vetpar.2014.07.033.

Nakamura AA, Meireles MV. Cryptosporidium infections in birds - a review. Rev Bras Parasitol Vet 2015; 24(3): 253-267. PMid:26444057. http://dx.doi.org/10.1590/S1984-29612015063.

Nakamura AA, Simóes DC, Antunes RG, Silva DC, Meireles MV. Molecular characterization of Cryptosporidium spp. from fecal samples of birds kept in captivity in Brazil. Vet Parasitol 2009; 166(1-2): 47-51. PMid:19683397. http://dx.doi.org/10.1016/j.vetpar.2009.07.033.

Nardi ARM. Ocorrência e caracterização molecular de Cryptosporidium spp. e Isospora spp. em uma população de canários do reino (Serinus canaria) que participam de campeonatos de ornitologia no Brasil [tese]. Campinas: Universidade Estadual de Campinas; 2015.

$\mathrm{Ng}$ J, Pavlásek I, Ryan U. Identification of novel Cryptosporidium genotypes from avian hosts. Appl Environ Microbiol 2006; 72(12): 7548-7553. PMid:17028234. http://dx.doi.org/10.1128/AEM.01352-06.

Qi M, Wang R, Ning C, Li X, Zhang L, Jian F, et al. Cryptosporidium spp. in pet birds: genetic diversity and potential public health significance. Exp Parasitol 2011; 128(4): 336-340. PMid:21557938. http://dx.doi. org/10.1016/j.exppara.2011.04.003.

Ravich ML, Reavill DR, Hess L, Childress AL, Wellehan JFX Jr. Gastrointestinal cryptosporidiosis in captive psittacine birds in the United States: a case review. J Avian Med Surg 2014; 28(4): 297-303. PMid:25843467. http://dx.doi.org/10.1647/1082-6742-28.4.297.

Reboredo-Fernández A, Ares-Mazás E, Cacciò SM, Gómez-Couso H. Occurrence of Giardia and Cryptosporidium in wild birds in Galicia (Northwest Spain). Parasitology 2015; 142(7): 917-925. PMid:25669618. http://dx.doi.org/10.1017/S0031182015000049.

Ryan UM, Xiao L, Read C, Sulaiman IM, Monis P, Lal AA, et al. A redescription of Cryptosporidium galli Pavlasek, 1999 (Apicomplexa: Cryptosporidiidae) from birds. J Parasitol 2003a; 89(4): 809-813. PMid:14533694. http://dx.doi.org/10.1645/GE-74RI.
Ryan U, Xiao L, Read C, Zhou L, Lal AA, Pavlasek I. Identification of novel Cryptosporidium genotypes from the Czech Republic. Appl Environ Microbiol 2003b; 69(7): 4302-4307. PMid:12839819. http://dx.doi. org/10.1128/AEM.69.7.4302-4307.2003.

Santos MMAB, Peiró JR, Meireles MV. Cryptosporidium infection in ostriches (Struthio camelus) in Brazil: clinical, morphological and molecular studies. Rev Bras Cienc Avic 2005; 7(2): 113-117. http:// dx.doi.org/10.1590/S1516-635X2005000200008.

Sevá AP, Funada MR, Richtzenhain L, Guimarães MB, Souza SO, Allegretti L, et al. Genotyping of Cryptosporidium spp. from free-living wild birds from Brazil. Vet Parasitol2011; 175(1-2): 27-32. PMid:21035268. http:// dx.doi.org/10.1016/j.vetpar.2010.09.031.

Silva DC, Homem CG, Nakamura AA, Teixeira WF, Perri SH, Meireles MV. Physical, epidemiological, and molecular evaluation of infection by Cryptosporidium galli in Passeriformes. Parasitol Res 2010; 107(2): 271277. PMid:20407911. http://dx.doi.org/10.1007/s00436-010-1858-2.

Slavin D. Cryptosporidium meleagridis (sp. nov.). J Comp Pathol 1955; 65(3): 262-266. PMid:13242675. http://dx.doi.org/10.1016/S03681742(55)80025-2.

Thompson JD, Gibson TJ, Plewniak F, Jeanmougin F, Higgins DG. The CLUSTAL_X windows interface: Flexible strategies for multiple sequence alignment aided by quality analysis tools. Nucleic Acids Res 1997; 25(24): 4876-4882. PMid:9396791. http://dx.doi.org/10.1093/nar/25.24.4876.

Thrusfield M, Ortega C, de Blas I, Noordhuizen JP, Frankena K. WIN EPISCOPE 2.0: improved epidemiological software for veterinary medicine. Vet Rec 2001; 148(18): 567-572. PMid:11370882. http:// dx.doi.org/10.1136/vr.148.18.567.

Wang TY, Wang L, Zhang JH, Dong WH. A simplified universal genomic DNA extraction protocol suitable for PCR. Genet Mol Res 2011; 10(1): 519-525. PMid:21476197. http://dx.doi.org/10.4238/vol10-1gmr1055.

Xiao L, Sulaiman IM, Ryan UM, Zhou L, Atwill ER, Tischler ML, et al. Host adaptation and host-parasite co-evolution in Cryptosporidium: Implications for taxonomy and public health. Int J Parasitol 2002; 32(14): 1773-1785. PMid:12464424. http://dx.doi.org/10.1016/ S0020-7519(02)00197-2.

Zhang XX, Zhang NZ, Zhao GH, Zhao Q, Zhu XQ. Prevalence and genotyping of Cryptosporidium infection in pet parrots in North China. Biomed Res Int 2015; 2015: 549798. 